\title{
Masonry Infill Walls Effect in Short Column Formation in Re Buildings: A Case Study
}

\author{
Mehrzad Mohabbi Yadollahi' ${ }^{1}$, Ahmet Benli ${ }^{1 *}$, Sadık Varolgüneş ${ }^{1}$ \\ ${ }^{1}$ Department of Civil Engineering, Bingol University, 12100, Bingol, Turkey
}

\begin{abstract}
The analyses of infill frame structures are generally done ignoring the presence of brick masonry in the analytical models but it is a prevalent mistake. Behaviors of such buildings vary significantly during the earthquake events. The lateral resisting capacity of infill wall actually restricts the column only up to the wall height but above the wall height, the free column deforms easily. In this paper, the effect of infill wall in formation of short column at military aid watchtower in Turkey has been analyzed and the analysis result compared with effect of earthquake that have been seen after earthquake.
\end{abstract}

Keywords: RC structures, Masonry infill walls, Short column, Earthquake

\section{Betonarme Binalarda Kısa Kolon Oluşumunda Dolgu Duvar Etkisi: Örnek Çalışma}

ÖZET: Dolgu duvar çerçeve yapılarının analizleri genellikle analitik modellerde tuğla duvar varlığını dikkate alınmadan yapılır fakat bu yaygın bir hatadır. Bu tür binaların davranışlar deprem durumunda önemli ölçüde değişmektedir. Dolgu duvarın yanal kuvvetlere dayanım kapasitesi gerçekte kolonu duvar yüksekliğine kadar olan bölümde sınırlamaktadır, duvar yüksekliğinin üstünde kalan kolon kolayca deforme olmaktadır. Bu çalışmada, Türkiye'de askeri bir karakol gözetleme kulesinde depremden dolayı oluşan kısa kolonda, dolgu duvar etkisi analiz edilmiş ve analiz sonucu deprem öncesi durumla karşılaştırılmıştır.

Anahtar Kelimeler: Betonarme yapılar, tuğla dolgu duvarlar, kısa kolon

\section{INTRODUCTION}

In the last few years, the scientific community has been hardly committed with the problem of evaluating the role of masonry infill both in the seismic response of infill frame buildings and in the damage progression. The problem is still open, and is particularly relevant in case of existing buildings that are designed with old standards, in which the infill panels are simply considered as nonstructural elements. Indeed, it is by now clear that the masonry infill strongly influence the structural seismic response and contribute to the overall stiffness, to the hysteretic dissipation capacity and can even modify the development of the failure mechanisms in the frames.

There are many reasons contributing to structural damage and the collapse of buildings during earthquakes. These include inappropriate placement of structure element like masonry infill walls, low quality concrete, incorrect construction techniques, poor detailing and inadequate construction supervision. In the last few decades, the scientific community has been extensively involved in the investigation about the interaction between infill masonry walls and RC frames in the seismic structural behavior, both for new and for existing buildings. This paper presents an extensive case study regarding the analysis of an existing $\mathrm{RC}$ framed building

* Corresponding author:Ahmet BENLİ abenli@bingol.edu.tr located in a high seismic risk area in Kigi, Turkey. The observation of post-earthquakes damages on reinforced concrete buildings has clearly shown that the presence of nonstructural elements, such as infill walls, may significantly affect the seismic performance of buildings, both in terms of seismic demand and capacity[1] [2].

For new buildings, the current European seismic codes assume that, if care has been taken to isolate the infill from the surrounding frames, the infill walls can be considered as secondary elements [3]. Recently, the influence of infill walls on the seismic structural response of RC buildings has been widely investigated by many research experimental and numerical studies $[4,5]$.

In particular, it was observed that the presence of correctly distributed infill elements can mitigate horizontal displacements and increase the overall resistance to horizontal actions. On the other hand, an uneven distribution in plan and in elevation may induce negative effects, fostering the occurrence of unexpected torsional actions and possibly increasing the seismic demand against sensitive zones where concentrations of stress or large ductility demands might prematurely cause collapse. During past earthquakes, reinforced concrete (RC) frame buildings that had columns of different heights within one story were damaged more in the shorter columns, as compared to taller columns in the 
same story. Poor behavior of short columns is due to the fact that in an earthquake, a tall column and a short column of the same cross-section move horizontally in same amount. However, the short column is stiffer as compared to the tall column, and it attracts a larger earthquake force, Stiffness of a column means resistance to deformation - the larger is the stiffness, larger is the force required to deform it. If a short column is not adequately designed for such a large force, it can suffer significant damage during an earthquake. This behavior is called Short Column Effect. The damage in these short columns is often in the form of X-shaped cracking-this type of damage of columns is due to shear failure. The shear failure of so-called "short columns» is a frequent cause of collapse during earthquakes [6].

\subsection{Situations That Occur Short Columns}

Many situations with short column effect arise in buildings, such as:

a. When a building is rested on sloped ground, during earthquake shaking all columns move horizontally by the same amount along with the floor slab at a particular level (this is called rigid floor diaphragm action). If short and tall columns exist within the same story level, then the short columns attract several times larger earthquake force and get damaged more compared to taller ones.

b. The short column effect also occurs in columns that support mezzanine floors or loft slabs that are added in between two regular floors.

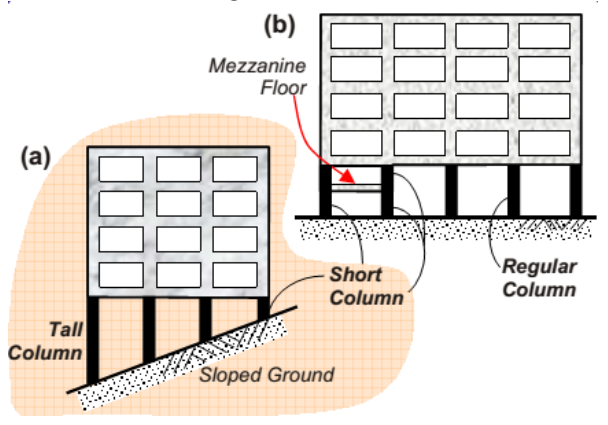

Figure1. a) Formation of short columns due to variation of column heights at the ground floor due to difference in ground level

b) Short column effect because mezzanine

c. There is another special situation in buildings where the short-column effect occurs. Consider a wall of partial height built to fit a window over the remaining height. The adjacent columns behave as short columns due to presence of these walls. In many cases, other columns in the same story are of regular height, as there are no walls adjoining them. When the floor slab moves horizontally during an earthquake, the upper ends of these columns undergo the same displacement. However, the stiff walls restrict the horizontal movement of the lower portion of a short column, and get deformed by the full amount over the short height adjacent to the window opening. On the other hand, regular columns get deformed over the full height. Since the effective height over which a short column can freely bend is small, it offers more resistance to horizontal motion and thereby attracts a larger force as compared to the regular column. As a result; the short column sustains more damage [1].

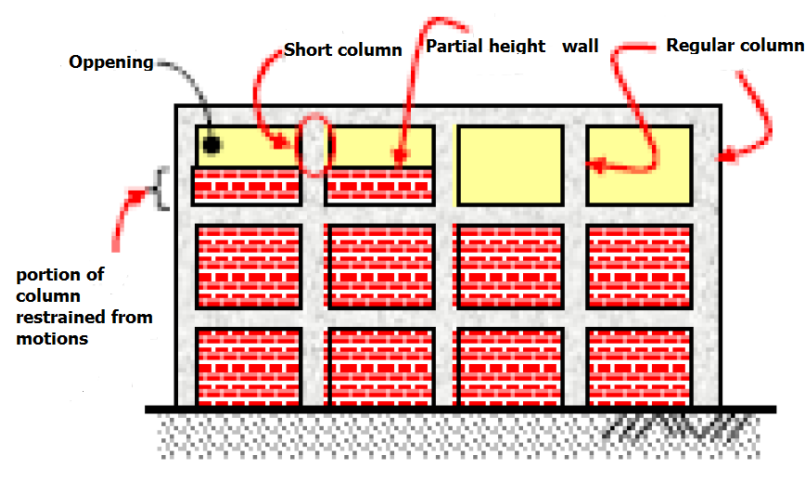

Figure 2. Formation of Short columns due to partial height of brick masonry infill wall

d. The short-column situation, as shown in Fig.3, is created by large window openings.

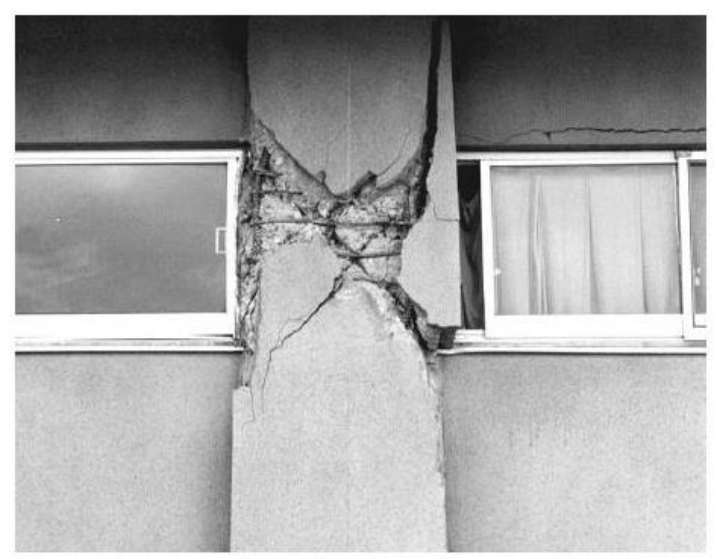

Figure 3. Large window openings and short column

e. Difference in levels can lead to short column (Fig.4, 5). 


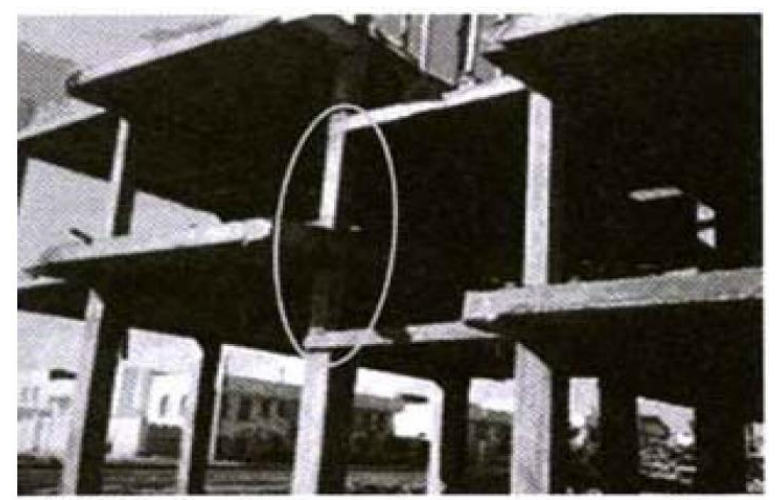

Figure4. Difference in levels (Dublex)

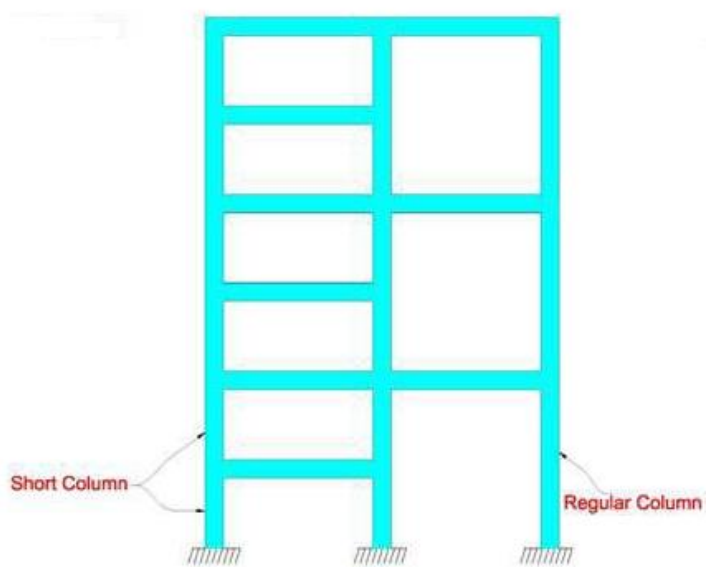

Figure5. Formation of short columns due to intermediate staircase landing beams between two floors

\subsection{Mechanism of Infill Masonry Walls}

Infill Masonry Walls are designed to perform architectural functions and there is a general agreement among researchers that infill frames have greater stiffness as compared to frames without infill walls. The presence of the infill walls increases the lateral stiffness considerably. Due to the change in stiffness and mass of the structural system, the dynamic characteristics change as well. The effects of the infill walls on the building response under seismic loading are very complex and math intensive [1]. The regular columns get deformed over the full height. Since the effective height over which a short column can freely bend is small, it offers more resistance to horizontal motion and thereby attracts a larger force as compared to the regular column. As a result, the short column sustains more damage [7].

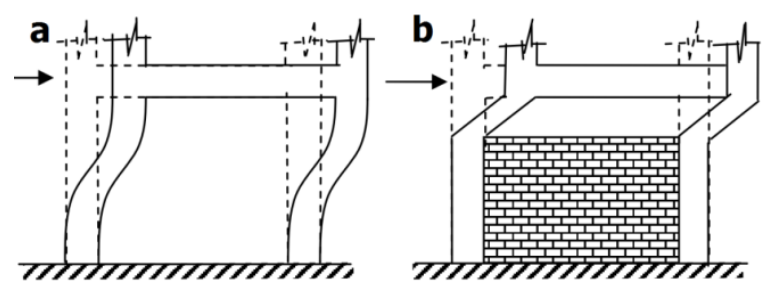

Figure 6. a) lateral deformation in bar frame b) Lateral deformation in partial infilled frame

\section{RESEARCH PURPOSE}

The analyses of infill frame structures are generally done ignoring the presence of brick masonry in the analytical models but it is a prevalent mistake among engineers. In this paper, the effect of infill wall in formation of short column at military aid watchtower in Turkey has been analyzed and the analysis result compared with realistic effect of earthquake that have been observed after earthquake by static linear analysis according TS500-2000.

\section{ANALYSIS OF THE STRUCTURE}

In this study, Analyses of the Structure have been done by ETABS standard package. The plan and section of watchtower has been illustrated in Fig.7. 


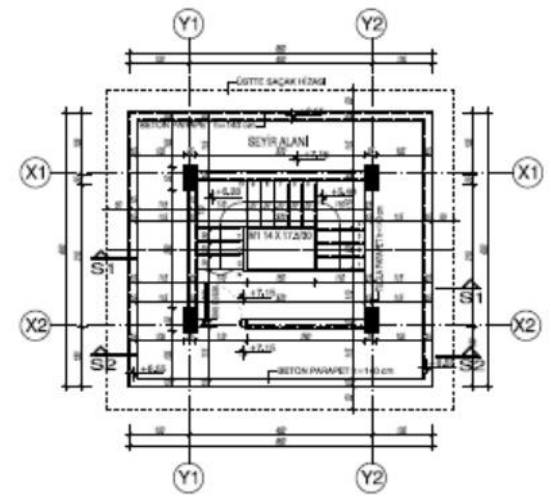

Plan 1:75

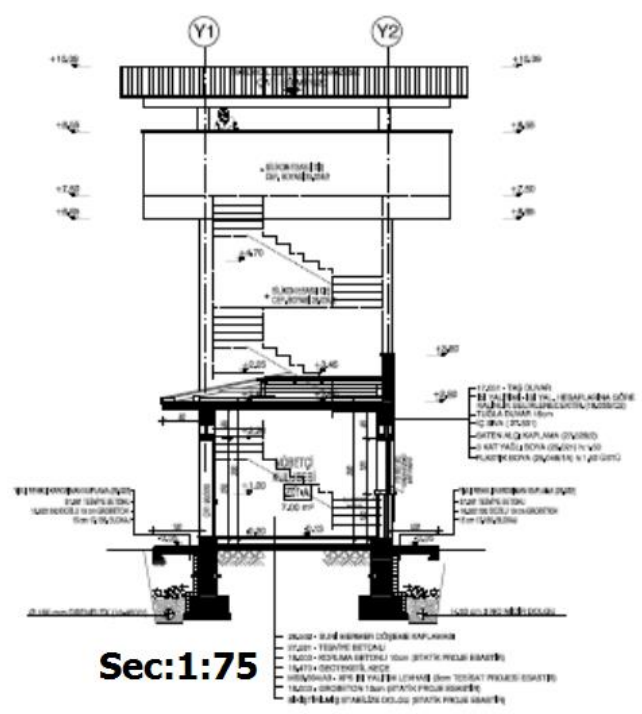

Figure 7. Plan and section of military watchtower

\subsection{Modeling in ETABS}

The building is modelled in ETABS in two approaches with brick infill walls and without brick infill walls by assumptions that have been given below (Fig. 8, 10).

- Damping of structure: $\% 5$

- Floors are modelled as rigid elements.

- Walls are modelled as shell elements.

- Beam column joints are taken as rigid joints.

- All supports are modelled as fixed supports.

- The system was assumed to be linearly elastic.

- For mass source $100 \%$ D.L and 30\% L.L is used. The mass is lumped at each story level

\subsection{Method}

- Type of frame: Reinforced Concrete moment resisting frame fixed at the base and reinforced Concrete moment resisting frame fixed at the base with shear wall

- Seismic zone: $1\left(\mathrm{~A}_{0}=0.40\right)$

- Number of story: 4

- Floor height: $2.45 \mathrm{~m}$

- Depth of Slab: $15 \mathrm{~cm}$

- Size of beam and column as shown in Table 1:

Table 1. Size of beams and columns

\begin{tabular}{ccc}
\hline Story & $\begin{array}{c}\text { Size of } \\
\text { Beam }(\mathrm{cm})\end{array}$ & $\begin{array}{c}\text { Size of } \\
\text { Column }(\mathrm{cm})\end{array}$ \\
\hline
\end{tabular}

\begin{tabular}{ccc}
\hline $\begin{array}{l}\text { Story1- } \\
\text { Story4 }\end{array}$ & $\begin{array}{l}\text { Only in fourth } \\
\text { floor B50*30 }\end{array}$ & C50*30 \\
\hline
\end{tabular}

- Live load on floors: $500 \mathrm{kgf} / \mathrm{m}^{2}$

- Live load on roof floor: $500 \mathrm{kgf} / \mathrm{m}^{2}$

- Dead load on floors: $150 \mathrm{kgf} / \mathrm{m}^{2}$

- Dead load on roof floor: $150 \mathrm{kgf} / \mathrm{m}^{2}$

- Wall load on external edges of roof floor: 350 $\mathrm{kgf} / \mathrm{m}$

- Materials: concrete $300 \mathrm{~kg} / \mathrm{cm}^{2}$, Rebar yield stress $4200 \mathrm{~kg} / \mathrm{cm}^{2}$ steel Material

- Thickness of shear Wall as shown in Table 2

Table 2. Thickness of shear Wall

\begin{tabular}{cc}
\hline Story & Thickness of shear wall $(\mathbf{c m})$ \\
\hline Story1- Story3 & $30 \mathrm{~cm}$ \\
\hline
\end{tabular}

\subsection{Analysis of the Structure without Brick Infill Wall Modeling}

In this model, walls of partial height have not been modeled and only the loads of the walls have been entered in to ETABS that has been shown in Fig.8. According to results, modeled Structure without brick infill wall has satisfied the project needs. ETABS results have been shown in Fig.9 all column color is blue or green and it means no structural problem. 


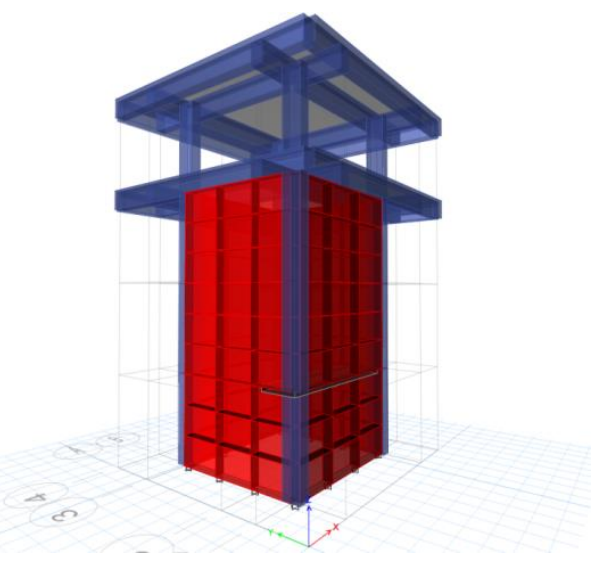

Figure 8. Structure modeling without brick infill wall

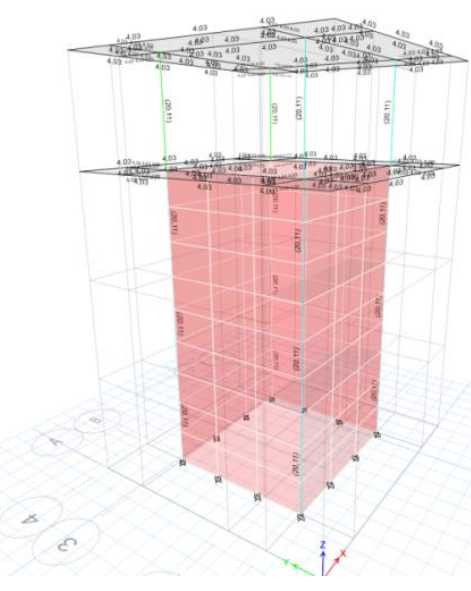

Figure 9. Results of Structure modeling without brick infill wall

\subsection{Analysis of the Structure by Brick Infill Wall Modeling}

In this model, walls of partial height have been used to fit a window over the remaining columns without column-wall isolation so short columns have been formed in fourth story columns Fig.10. Because these columns are not designed for such a large force, it can suffer significant damage after earthquake as you see in Fig.11 the short columns cannot bear the earthquake force and have been failed.

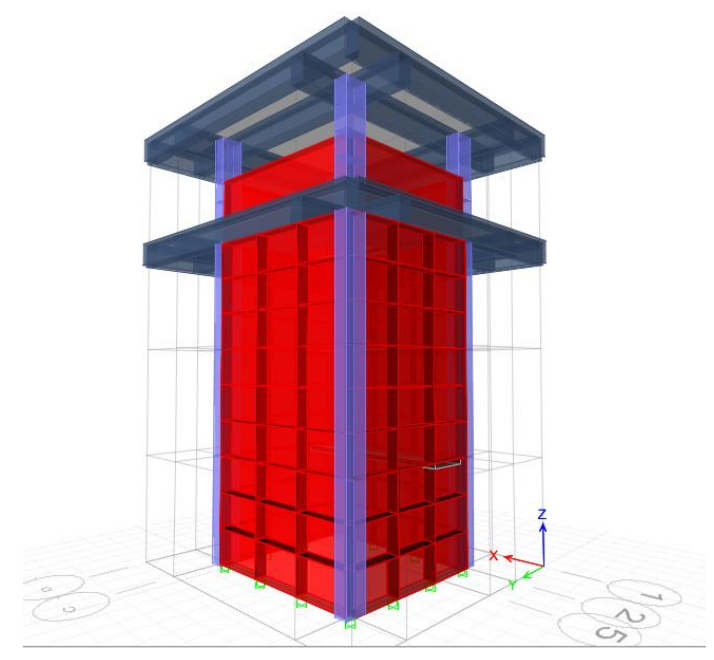

Figure 10. Structure modeling by brick infill wall

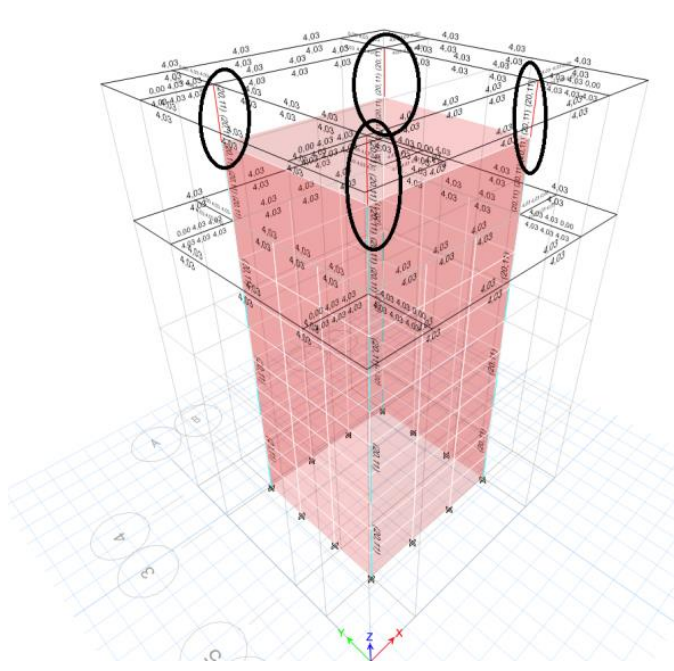

Figure 11. Results of Structure modeling by brick infill wall

\section{DISCUSSION}

The analyses of infilled frame structures are generally done ignoring the presence of brick masonry in the analytical models but it is a prevalent mistake. The building is modelled by ETABS in two ways, with brick infill walls and without brick infill walls. When we use wall of partial height built to fit a window over the remaining the adjacent columns 
behave as short columns due to presence of these walls. The short column is stiffer as compared to the tall column, and it attracts a larger earthquake force, Stiffness of a column means resistance to deformation the larger stiffness, the larger required force to deform. If a short column is not adequately designed for such a large force, it can suffer significant damage during an earthquake as you see in Fig.11 the short columns cannot bear the earthquake force and have been cracked like Fig.12. But we have no problem in Results of Structure modeling without brick infill wall the columns have seen shown in Fig.9. So Solution for this type of problems is very simple: isolation the infill brick walls from the surrounding frames.

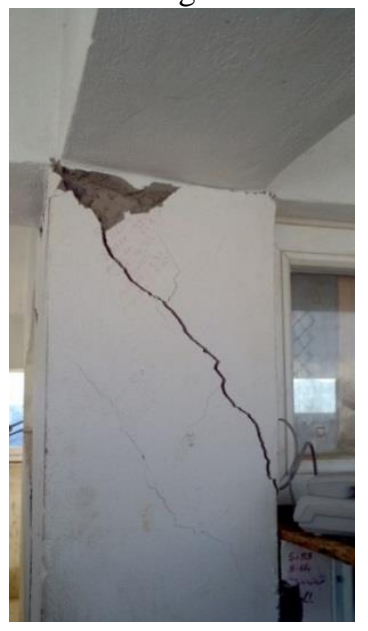

Figure 12. Short column damage in our study

\section{CONCLUSION}

-Strength of masonry infill, even though considered non-structural, influence the lateral behavior of $\mathrm{RC}$ frames.

- Structural drift is reduced by infills, because of reduced ductility of RC frames, and columns in particular.

-Shear force in short column in RC frames increases, owing to the presence of infills which leads to failure of the structure.
-A partial infilled short columns structure attracts larger force and sustains critical damage.

-During the lateral loads improper shear flow due to partially infilled structures will damage the short column leading to structural failure.

-Solution for this type of problems is isolation the infills from the surrounding frames.

\section{REFERENCES}

[1]. Mosalam, K. M., and Gunay, S. (2015). "Progressive Collapse Analysis of Reinforced Concrete Frames with Unreinforced Masonry Infill Walls Considering In-Plane/Out-of-Plane Interaction." Earthq Spectra, 31(2), 921-943.

[2]. Uva, G., Porco, F., and Fiore, A. (2012). "Appraisal of masonry infill walls effect in the seismic response of $\mathrm{RC}$ framed buildings: A case study." Eng Struct, 34, 514-526.

[3]. (CEN. Eurocode -2005). "Design of structures for earthquake resistance. Part 3: Assessment and retrofitting of buildings."Brussels.

[4]. Negro P, and A., C. (1997). "Irregularities induced by non-structural masonry panels in framed buildings." Eng Struct, 10.

[5]. Dolsek, M., and Fajfar, P. (2005). "Simplified non-linear seismic analysis of infilled reinforced concrete frames." Earthq Eng Struct D, 34(1), 49-66. [6]. Khalilzadeh Vahidi, E., and Mokhtari Malekabadi, M. (2009). "Conceptual Investigation of Short-Columns and Masonary Infill Frames Effect in the Earthquakes." International Journal of Civil, Environmental, Structural, Construction and Architectural Engineering 3(11).

[7]. Prachand Man, P., Prajwal, L. P., and Ramesh, K. M. (2012). "Lateral strength of partial masonry infill wall in concrete frame under static load." Journal of Civil Engineering (IEB) 40(1), 66-77. 